\title{
CLIMATIC PARAMETERS OF SEASONAL AIR AND GROUND FROST IN THE ROMANIAN PLAIN REGION
}

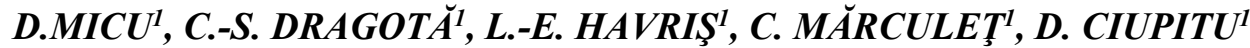

\begin{abstract}
Climatic parameters of seasonal air and ground frost in the Romanian Plain Region: a weather hazard for agriculture. The present study investigates the regional features of a highly recurrent winter meteorological phenomenon, with costly and adverse effects on the croplands of the Romanian Plain, one of the most important agricultural regions of Romania. The analyses are focused on the characteristics of air and ground frost, but also on their joint action, for understanding the exposure to cold stress of croplands in a changing climate. The study uses the daily minimum air temperature and mean daily surface soil mean temperature of the gridded ROCADA dataset (1961-2013), extracted for 10 representative weather station locations from the corresponding grid cells, to compute five relevant parameters of air and ground frost and to analyse subsequent trends in their variability across the region. A Mann-Kendall trend analysis (MK) was also performed for each air and ground frost-related parameters to study the changes in cold (freezing) stress at regional scale. The study presents the climatological traits of air and ground frost across the region, typically affecting it from mid-to-late autumn until early-to-mid spring. Air frost season is generally longer than the ground frost season, in relation to its earlier autumn onset and later spring offset dates. The region has a moderate exposure to frost damage risk of crops when considering the seasonal frequency of joint air and ground frost action days. MK analysis for the selected air and ground frost parameters revealed mixed trends, mostly with no statistically significance and some of them disconnected from the ongoing climate warming which affects the region. The changes frost parameters, mainly in those related to ground frost, could partially explain the expansion trend of the agricultural growing season, as well as some changes in crop development stages, especially of cereal crops.
\end{abstract}

Keywords: air and ground frost, climate change, the Romanian Plain.

\section{INTRODUCTION}

Closely linked to the temperature variations in the air and on the ground, frost is key weather hazard with important implications for agriculture, hydrology and human health and could also serve as a reliable indicator of winter severity. The observed changing climate over the last several decades has been found as a factor altering the timing and patterns of freezing in several agricultural regions of Europe, favouring a lengthening of growing season and the extension of frost-free period (e.g. Olensen and Bindi, 2002).

Southern Romania is a "climate change hot spot region" and is under a visible and significant warming trend over the last 50 years (e.g. Dumitrescu et al., 2015; Croitoru and

\footnotetext{
1 Romanian Academy, Institute of Geography, 023993, Bucharest, Romania, e-mail: micudanamagdalena@gmail.com; dragotacarmensofia@gmail.com.
} 
Piticar, 2013). This region has warmed up especially in summer. In winter and spring warming is weaker but still significant, showing no prominent behaviour in autumn. Over the recent decades, southern Romania experienced visible changes in the frequency and severity of extreme temperature events: e.g. significant and widespread increase of heat stress in most seasons (especially in summer), decreasing frequency of air frost days and cold waves in some plain areas of southern Romania (e.g. Croitoru and Piticar, 2013; Busuioc et al., 2015; Piticar et al., 2017).

The present study investigates the key climatic frost parameters and the subsequent trends over the 1961-2013 period in the Romanian Plain region, one of the most important agricultural regions of Romania. The analyses are focused on the characteristics of air and ground frost, but also on their joint action, for determining the changes in the exposure to cold (freezing) stress of croplands. The drawback of this approach is related to the fact that, under the ongoing climate change, the phenological sensitivity in croplands is also related to other meteorological parameters (e.g. snow cover, soil water content), that could also produce detrimental effects, besides the minimum air temperatures and soil mean temperatures. For example, acknowledging the crop growth sensitivity to temperature, Petcu et al. (2007) highlighted the complexity of weather-crop development relationships, showing that frost tolerance of crop plants was closely related to the tolerance to severe frost-induced dehydration. The main objective of this study is to analyse the seasonal behaviour of freezing temperatures (in the air and on the ground), in order to understand the frost risk and the exposure to frost damage of croplands in southern Romania, in a changing climate.

\section{DATA AND METHODS}

This study is based on the daily minimum air temperature and daily surface soil mean temperature time-series of the gridded climatic dataset ROCADA (Bîrsan and Dumitrescu, 2015), with a spatial resolution of $0.1 \times 0.1^{\circ}$, covering $1961-2013$. This dataset integrates measurements from all weather stations with full data records (150 stations for minimum temperature and 127 stations for soil temperature) and missing data up to $30 \%$ in the monitoring network of the National Meteorological Administration. This dataset is homogenized and gridded using MASHv3.03 (Multiple Analysis of Series for Homogenization) and MISH (Meteorological Interpolation based on Surface Homogenized Data) software packages, both developed by the Hungarian Meteorological Service (e.g. Szentimrey, 1999; Szentimrey and Bihari, 2004).

For this study, we selected a number of 10 weather stations of the Romanian Plain region (Fig. 1), for whose locations we extracted temperature data from the corresponding ROCADA grid cells, to calculate six indicators describing the climatology of air frost and ground frost, namely: the average date of the first autumn frost ( $\mathrm{FA}_{\text {air }}$ and $\mathrm{FA}_{\text {ground }}$ ), the average date of the last spring frost ( $\mathrm{LS}_{\text {air }}$ and $\mathrm{LS}_{\text {ground }}$ ), frost season length (FSLair and FSL ground), frost intensity ( $\mathrm{FI}_{\text {air }}$ and $\left.\mathrm{FI}_{\text {ground }}\right)$, frost-free season length ( $\mathrm{FFS}_{\text {air }}$ and $\mathrm{FFS}_{\text {ground }}$ ) and the number of days with joint frost action in the air and on the ground (JFA). 


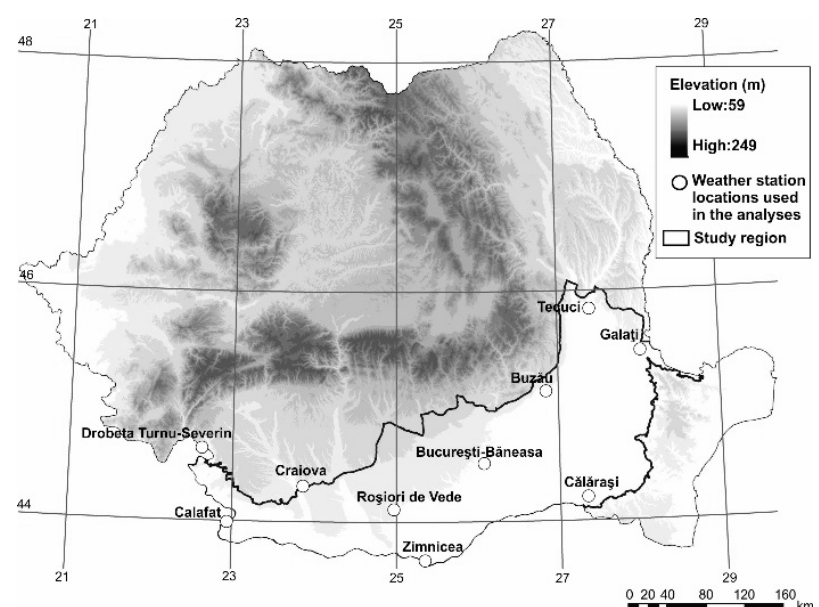

Fig. 1. Location of the study region, topography and weather stations selected for analyses

Trend analysis in the five frost indices has been done using the non-parametric Mann-Kendall (MK) test. For the purposes of this study, the significance level in trend estimates was set to $10 \%$ (two-tailed).

\section{RESULTS}

\subsection{Regional climatology of air and ground frost}

In southern Romania, air frost and ground frost are highly recurrent meteorological phenomena during the cold season. The timing of frost across the region is highly variable both in time and space, showing dominant earlier onsets ( $70-80 \%$ cases) of frost in the air than on the ground in autumn and an opposite (offset) situation in spring. The probability of simultaneous occurrence of frost both in the air and on the ground is rather low (8 to 13\%) over the time-period investigated, corresponding to up to 7 cases in autumn and up to 4 cases in spring. In terms of average onset and offset dates, air frost typically lasts from the late October or early November $\left(\mathrm{FA}_{\text {air }}\right)$ until the late March or early April (LS ${ }_{\text {air }}$ ), while ground frost lasts from mid-November or early December (FAground until early-to-mid March (LSground). This time-interval is particularly prone to persistent surface temperature inversions, as this region (as part of the wide Carpathian-Balkan Depression lying at the outer border of the East-European High) act as a veritable cold air pool of the cold continental airflows, favoring long-lasting freezing, snow cover and foggy weather. Table 1 summarizes the timing of air and ground frost phenomenon in the Romanian Plain region.

Exposure to frost risk and subsequent crop damage depends on multiple factors (e.g. Eccel et al., 2009; Pagagiannaki et al., 2014), including the frost season length (FSL). In this study, FSL was determined in relation to the average onset and offset dates of air and ground frost (FSLair and FSLground). On average, FSLair across the Romanian Plain region ranges between 145 days in the westernmost areas (at Drobeta Turnu-Severin) and 160-164 days in the north-eastern areas (Buzău, Râmnicu Sărat and Tecuci) and in the 
some Danube Floodplain areas (Călăraşi). FSLair is 30 up to 62 days longer thanFSLground, which varies spatially from less than 100 days in the eastem plain areas (Tecuci and Călăraşi) to over 115-120 days in the western ones (Calafat and Drobeta Tr. Severin).

Table 1. The timing of air and ground frost in autumn and spring across the Romanian Plain region

\begin{tabular}{|c|c|c|c|c|c|c|c|c|c|c|}
\hline \multirow{2}{*}{$\begin{array}{l}\text { Weather station grid } \\
\text { cell locations }\end{array}$} & \multicolumn{5}{|c|}{ Autumn } & \multicolumn{5}{|c|}{ Spring } \\
\hline & 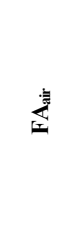 & 竧 & 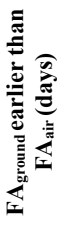 & 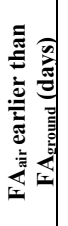 & 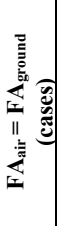 & 点 & 曾 & 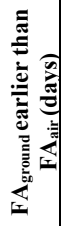 & 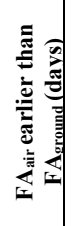 & 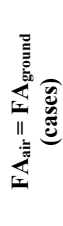 \\
\hline Drobeta Tr. Severin & Nov.3 & Nov.14 & 56 & 42 & 7 & Mar.28 & Mar.14 & 64 & 10 & 2 \\
\hline Calafat & Nov.1 & Nov. 15 & 52 & 4 & 6 & Mar.23 & Mar.11 & 49 & 7 & 4 \\
\hline Craiova & Oct.29 & Nov. 25 & 57 & 10 & 4 & Apr.1 & Mar.11 & 52 & 9 & 0 \\
\hline Roșiori de Vede & Oct. 28 & Oct.20 & 61 & 0 & 2 & Apr.2 & Mar.8 & 71 & 2 & 2 \\
\hline Zimnicea & Nov.4 & Nov. 25 & 60 & 0 & 2 & Mar.30 & Mar.4 & 77 & 0 & 0 \\
\hline București-Băneasa & Oct.29 & Nov. 27 & 64 & 0 & 2 & Apr.6 & Mar.6 & 69 & 0 & 0 \\
\hline Călărași & Oct. 27 & Nov. 27 & 62 & 0 & 1 & Apr.5 & Mar.5 & 79 & 22 & 1 \\
\hline Buzău & Oct.29 & Nov. 2 & 62 & 0 & 2 & Apr.2 & Mar.5 & 75 & 0 & 0 \\
\hline Galaţi & Oct.24 & Dec.1 & 60 & 0 & 2 & Apr.5 & Mar.7 & 79 & 0 & 1 \\
\hline Tecuci & Oct.24 & Dec.1 & 70 & 0 & 0 & Apr.5 & Feb.25 & 93 & 0 & 0 \\
\hline
\end{tabular}

Note: $\mathrm{FA}_{\text {ground }}$ earlier than $\mathrm{FA}_{\text {air }}$ and $\mathrm{FA}_{\text {air }}$ earlier than $\mathrm{FA}_{\text {ground }}$ indicate the maximum delay (days) between the two onsets/offsets; $\mathrm{FA}_{\text {air }}=\mathrm{FA}_{\text {ground }}$ represents the number of cases with simultaneous occurrence of frost in the air and on the ground.

Within these time-intervals, individual frost events could affect the region in persistent cold spells (at least 5 consecutive days with minimum air temperatures below P10\%), under the influence of the easterly cold continental airflows of East-European origins. Documenting two historical severe winters in southern Romania (1953/1954 and 2011/2012), Bogdan et al. (2013) showed that the Romanian Plain region, especially its easternmost areas, experienced intense and persistent frosts associated to heavy snowstorms and wind gusts in January 1954 and more recently, between January 2011 and February 15, 2012, causing significant societal and economic impacts (e.g. population isolation, road and railway transport disturbances and blocking). In these winters, individual air frost events lasted up to 9 consecutive days over 22-31 January 1954 and up to 19 consecutive over January 31-February 18, 2012, over extended areas. In both winters, frost intensities exceeded $-20^{\circ} \mathrm{C}$ across the study region.

The annual frequency of persistent cold spells across the region ranges between 15 to 27 cases/per period, winter months having a share of over $50 \%$ in the total annual number of cases in most locations. The maximum duration of an individual cold-frost spell reached exceptional values in some central (21 days/1963 at Roşiori de Vede) and eastern areas (18 days/1985 at Galaţi) (Table 2).

Frost intensity is an important indicator of cold hardiness and cold stress in agriculture, especially in relation to the critical biological resistance threshold to frostfreeze $\left(-20 \ldots-15^{\circ} \mathrm{C}\right)$ of crop plants (Sandu et al., 2010). In persistent cold spells, this critical threshold is frequently reached or exceeded throughout the entire region (Table 2), exposing the autumn crops (e.g. winter wheat, rye, barley) to an intense and prolonged freezing stress, especially when snow layer is inconsistent or lacks. Mueller et al. (2015) 
showed that some varieties of wheat could resist to freezing temperatures lower than $-20^{\circ} \mathrm{C}$ in their early development stages, in general, wheat and maize cannot tolerate frost during their main growth period.

Table 2. Characteristics of persistent cold spells with frost occurrences in the Romanian Plain region (1961-2013)

\begin{tabular}{|l|c|c|c|}
\hline $\begin{array}{l}\text { Weather station grid } \\
\text { cell locations }\end{array}$ & $\begin{array}{c}\text { Annual frequency of } \\
\text { persistent cold spells } \\
\text { (cases/53 years) }\end{array}$ & $\begin{array}{c}\text { Maximum duration of individual } \\
\text { cold spells with frost occurrence } \\
\text { (days/year) }\end{array}$ & $\begin{array}{c}\text { Peak frost intensity } \\
\text { in a cold spell event } \\
\left({ }^{\circ} \mathbf{C}\right)\end{array}$ \\
\hline Drobeta Tr. Severin & 22 & $14 / 1985$ & -25.1 \\
\hline Calafat & 27 & $7 / 1963,1985,2005$ & -25.3 \\
\hline Craiova & 22 & $9 / 1985$ & -28.2 \\
\hline Roşiori de Vede & 20 & $21 / 1963$ & -27.9 \\
\hline Zimnicea & 17 & $8 / 1985,1989$ & -26.5 \\
\hline Bucureşti-Băneasa & 17 & $10 / 1985$ & -24.3 \\
\hline Călăraşi & 15 & $9 / 1985$ & -26.1 \\
\hline Buzău & 21 & $7 / 1994$ & -23.7 \\
\hline Galați & 17 & $18 / 1985$ & -23.5 \\
\hline Tecuci & 19 & $9 / 1985$ & -26.1 \\
\hline
\end{tabular}

The intensity of frost at its autumn onset and spring offset is highly variable across the regions, showing different situations: i) $\mathrm{FI}_{\text {ground }}$ higher than $\mathrm{FI}_{\text {air }}$ in autumn (generally with $1.2-4.9^{\circ} \mathrm{C}$ ) at Drobeta Turnu-Severin, Roşiori de Vede, Zimnicea and Galaţi; ii) $\mathrm{FI}_{\text {ground }}$ higher than $\mathrm{FI}_{\text {air }}$ in spring (with $0.9^{\circ} \mathrm{C}$ ) only at Zimnicea; iii) $\mathrm{FI}_{\text {air }}$ higher than $\mathrm{FI}_{\text {ground }}$ in autumn (with $0.5-3.4^{\circ} \mathrm{C}$ ) at Calafat, Buzău, Tecuci, Bucureşti-Băneasa; and iv) $\mathrm{FI}_{\text {air }}$ higher than $\mathrm{FI}_{\text {ground }}$ in spring (with 1.2 to $9.0^{\circ} \mathrm{C}$ ) in most locations (Drobeta Turnu-Severin, Roşiori de Vede, Calafat, Buzău, Galaţi, Tecuci, Bucureşti-Băneasa and Craiova). In all cases, both $\mathrm{FI}_{\text {air }}$ and $\mathrm{FI}_{\text {ground }}$ during autumn onsets and spring offsets did not reached or exceed the critical biological thresholds, generally maintaining below $-10^{\circ} \mathrm{C}$ even during the cold autumns and springs.

Frost-free season, here defined as the period between the last spring frost and the first autumn frost within the same year, has a dominant duration relative to frost season, for both its components ( $\mathrm{FFS}_{\text {air }}$ and $\mathrm{FFS}_{\text {ground }}$ ). $\mathrm{FFS}_{\text {air }}$ is 20 to $39 \%$ more extended than $\mathrm{FS}_{\text {air }}$ (corresponding to a variation range of 200-220 days), while $\mathrm{FFS}_{\text {ground }}$ is 50 to $69 \%$ longer than $\mathrm{FS}_{\text {ground }}$ (245 to 279 days). The central and western plain areas, more influenced by the Mediterranean air flows, have in general the longest FFS air $_{\text {(over }}$ 210 days - Drobeta Turnu-Severin, Roşiori de Vede, Calafat and Craiova), while some southern, eastern and north-eastern plain and floodplain areas experience longer FFS $_{\text {ground }}$ (over 265 days - Buzău, Zimnicea, Călăraşi and Tecuci).

\subsection{The interaction of air and ground frost}

Intense and persistent frost events both in the air and on the ground could substantial impact crop production (Snyder et al., 2005). Here, we investigate the cumulative effect both types of extremes across the Romanian Plain region, in terms of the frequency of the number of days with joint frost action both in the air and on the ground (JFA). JFA could be seen as a frost damage indicator of croplands. On average, seasonal JFA encompass a limited value range across the region (between 40 days 
at Tecuci and 67 days at Calafat). In most the locations, JFA represents 30 to $40 \%$ in the total duration of the cold half of the year (October-March), except for some southern, central and eastern plain and floodplain areas (Zimnicea, Tecuci and Bucureşti-Băneasa), where JFA accounts less than 30\%. By means of average JFA, the Romanian Plain region has a moderate exposure to frost damage risk. Throughout the region, JFA covers the November-March interval. During winter months, simultaneous frost occurrence, both in the air and on the ground, is very likely in more than 15-20 days per month, while in the late-autumn and early spring months (November and March), its frequency is less than 510 days. However, during the cold winters of the period (e.g. 1962/1963, 1984/1985) the region experienced an increased frost damage risk, as JFA exceeded 80-90 days even in the plain and floodplain areas less exposed in average conditions.

\subsection{Observed changes in air and ground frost climatology}

The MK statistics indicate mixed trends in frost parameters, revealing different change patterns, mostly with no statistically significance and sometimes disconnected from the ongoing climate warming which affects the region. Table 3 is summarizing the results of trend analyses in air and ground frost parameters in the Romanian Plain region (1961-2013).

Table 3. Trends and estimated changes (days/53 years) in air and ground frost climatological parameters in the Romanian Plain region over 1961-2013

\begin{tabular}{|l|c|c|c|c|c|c|c|c|c|}
\hline $\begin{array}{l}\text { Weather station grid } \\
\text { cell locations }\end{array}$ & FA $_{\text {air }}$ & FA ground $_{\text {glir }}$ & LS $_{\text {air }}$ & LS $_{\text {ground }}$ & FSLair & FSL ground $_{\text {JFA }}$ & FFS $_{\text {air }}$ & FFS $_{\text {ground }}$ \\
\hline Drobeta Tr. Severin & -8.0 & $*$ & $*$ & -4.6 & 10.6 & -8.8 & -11.6 & -6.9 & 9.5 \\
\hline Calafat & $\mathbf{- 1 7 . 7}$ & -4.6 & 6.6 & 3.5 & $\mathbf{2 6 . 5}$ & 5.0 & $\mathbf{- 1 3 . 3}$ & $\mathbf{- 2 4 . 0}$ & -5.1 \\
\hline Craiova & $*$ & $*$ & -8.9 & -4.1 & -6.6 & -5.2 & -9.6 & 9.1 & 7.8 \\
\hline Roşiori de Vede & -2.3 & 4.4 & -2.8 & -4.6 & 4.2 & -9.5 & $\mathbf{- 1 4 . 3}$ & 1.5 & 11.7 \\
\hline Zimnicea & 1.2 & 1.8 & 2.5 & $\mathbf{- 8 . 8}$ & 3.8 & -11.7 & -9.6 & -3.8 & 8.0 \\
\hline Bucureşti-Băneasa & -2.5 & 5.2 & $*$ & -1.6 & 3.7 & -5.2 & -10.6 & $*$ & 7.8 \\
\hline Călăraşi & 4.3 & $*$ & -0.5 & -7.8 & -10.4 & -6.0 & -10.8 & 8.5 & 9.5 \\
\hline Buzău & 3.2 & 6.7 & -5.8 & -4.1 & -7.4 & -9.6 & $\mathbf{- 1 1 . 8}$ & 8.9 & $*$ \\
\hline Galaţi & $*$ & $*$ & $*$ & -4.1 & 3.0 & -2.7 & $\mathbf{- 1 4 . 0}$ & $*$ & 4.7 \\
\hline Tecuci & 7.4 & 5.6 & -2.9 & $*$ & $\mathbf{- 1 3 . 3}$ & -5.9 & -8.3 & $\mathbf{1 3 . 3}$ & 8.4 \\
\hline
\end{tabular}

Statistically significant trends $(\mathrm{p}$-value $<0.1)$ are marked in bold.

* no trend

In autumn, the changes in frost onset are visibly inconsistent (sign agreement and statistical significance) for both components ( $\mathrm{FA}_{\text {air }}$ and $\left.\mathrm{FA}_{\text {ground }}\right)$, but especially in the air. Even though observable in only a few central and western plain areas of the region (Drobeta Turnu-Severin, Roşiori de Vede and mostly at Calafat), air frost is tending to onset up to two weeks earlier. Autumn ground frost tends to start up to one week later in most locations, but with no statistically significance. In spring, the trends are also mixed, but they suggest a widespread signal of an earlier offset of ground frost (LS $\mathrm{S}_{\text {ground }}$ ), statistically significant only in the Danube Floodplain, at Zimnicea.

Under the recent warming, frost season length across the region shows different behaviours, with a poor statistically significance. While $\mathrm{FSL}_{\text {air }}$ remains rather constant 
(e.g. Roşiori de Vede, Zimnicea, Galaţi), slightly decreases (with up to 13 days at Tecuci) or increases (up to 27 days at Calafat), FSLground is on a more generalized decrease, mainly due to the spring offset changes. Despite the weak trends, $\mathrm{FSL}_{\text {ground }}$ is on a widespread lengthening ( 5 up to 12 days longer), reflecting better the climate warming. These results could explain partially the expansion trend of the agricultural growing season, as well as some changes in crop phenology (e.g. sowing, flowering, maturing), rising both challenges and opportunities for agricultural productivity and yields, especially for cereal crops.

Temperature increase over the past few decades would reduce the risk of frost damage across the region. The trends in JFA and its estimated changes support this conclusion. The frequency of days when frost action is simultaneous in the air and on the ground is on a general decrease with 8 to 14 days/period. For this indicator, MK returned the greatest number of statistically significant local trends within the region, found in four out of the total 11 selected locations (Table 3 ). The general decrease in JFA is mostly due to the decreasing frequency of seasonal ground frost days.

The weakest and the most inconsistent trends have been found in frost intensity during the autumn onset and spring offset, both in the air and on the ground (not shown in Table 3).

\section{CONCLUSIONS}

Air frost and ground frost are highly recurrent cold season phenomena across the southern plain areas of Romania, from mid-to-late autumn until early-to-mid spring, until under the influence of cold continental airflows, which favours longlasting freezing, snow cover and foggy weather. The air frost season across the region is generally longer than the ground frost season (30 to 62 days), while the frost-free interval is typically more extended than the frost season, for both its air and ground components. Frost intensity during the autumn onsets and spring offsets of the phenomenon stays generally below $-10^{\circ} \mathrm{C}$, reaching or overshooting the critical biological threshold for crops during the persistent cold waves (freezing temperatures below $-20^{\circ} \mathrm{C}$ ).

The region has a moderate exposure to frost damage risk, as the average frequency of days with simultaneous action of air and ground frost accounts only 30 to $40 \%$ in the total duration frost season. The main findings of frost trend analysis indicate: in autumn and spring, most changes (sign agreement between local trends) are related to ground frost, showing a trend toward later onsets and earlier offsets over extended plain areas; frost season length is on a more generalized decrease for the ground component, reflecting better the climate warming effects; the frequency of days with joint air and ground frost action is on a general decrease, mainly due to the decreasing frequency of seasonal ground frost days. Some observed changes in frost parameters, mainly for the ground component of the phenomenon (e.g. LS ground,

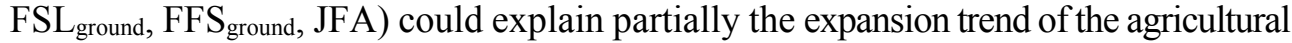
growing season across the region, as well as the changes in the timing of some crop development stages, influencing the agricultural productivity and yields, especially for cereal crops. 


\section{Acknowledgements}

This work was conducted in the framework of the Romanian Academy research project entitled Climate hazards in the Romanian Plain Region (2017).

\section{REFERENCES}

1. Bîrsan, M.V., Dumitrescu, A. (2015), Rocada: a gridded daily climatic dataset over Romania (1961-2013) for nine meteorological variables, Nat. Haz., 78(2): 10451063.

2. Bogdan, O., Marinică, A.F., Marinică I. (2013), Comparative climatic characteristics between the winter of 2011-2012 and the winter of 1953-1954 in the Southern of Romania, Rev. Roum. Géogr., 57 (1): 9-24.

3. Busuioc, A., Dobrinescu, A., Bîrsan, M.V., Dumitrescu, A., Orzan, A. (2015), Spatial and temporal variability of climate extremes in Romania and associated large-scale mechanisms, Int. J. Climatol., Doi: 10.1002/joc.4054.

4. Croitoru, A.-E., Piticar, A. (2013), Changes in the daily extreme temperatures in the extra-Carpathians regions of Romania, Int. J. Climatol., 33: 1987-2001.

5. Dumitrescu, A., Bojariu, R., Bîrsan, M.V., Marin, L., Manea, A. (2015), Recent climatic changes in Romania from observational data (1961-2013), Theor. Appl. Climatol., 122, 1-2.

6. Eccel, E., Rea, R., Caffarra, A., Crisci, A. (2009), Risk of spring frost to apple production under future climate scenarios: the role of phenological acclimation, Int. J. Biometeorol., 53: 273-286.

7. Olensen, J.E., Bindi, M. (2002), Consequences of climate change for European productivity, land use and policy, European Journal of Agronomy, 16(4): 239-262.

8. Mueller, B., Hauser, M., Iles, C., Rimi, H.R., Zwiers, F.W., Wan, H. (2015), Lengthening of the growing season in wheat and maize producing regions, Weather and Climate Extremes, 9: 47-56.

9. Papagiannaki, K., Lagouvardos, K., Kotroni, V., Papagiannakis, G. (2014), Agricultural losses related to frost events: use of the $850 \mathrm{hPa}$ level temperature as an explanatory variable of the damage cost, Nat. Hazards Earth Syst. Sci., 14: 23752386.

10. Petcu, E., Țerbea, M., Lazăr, C. (2007), Cercetări în domeniul fiziologiei plantelor de câmp la Fundulea, AN. I.N.C.D.A. Fundulea, LXXV.

11. Piticar, A., Croitoru, A.-E., Ciupertea, F.-A., Harpa, G. (2017), Recent changes in heat waves and cold waves detected based on excess heat factor and excess cold factor in Romania. Int. J. Climat., Doi: 10.1002/joc.5295.

12. Sandu, I., Mateescu, E., Vătămanu, V. (2010), Schimbări climatice în România şi efectele asupra agriculturii, Edit. Sitech, Bucureşti, 406 p.

13. Snyder R.L., Melo-Abreu J.P., Matulich S. (2005), Frost protection: fundamentals, practice and economics, vol. 2. London: FAO, $\mathrm{v}+64 \mathrm{p}$.

14. Szentimrey, T. (1999), Multiple Analysis of Series for Homogenization (MASH). Proceedings of the 2nd Seminar for Homogenization of Surface Climatological Data. Budapest, Hungary. WMO, WCDMP-No. 41: 27-46.

15. Szentimrey, T., Bihari, Z. (2004), Mathematical background of the spatial interpolation methods and the software MISH (Meteorological Interpolation based on Surface Homogenized Data Basis), Proceedings from the Conference on Spatial Interpolation in Climatology and Meteorology, COST 719 Meeting, Budapest, Hungary, 24-29 October. 